\title{
SPLEEN-PRESERVING DISTAL PANCREATECTOMY IN THE MANAGEMENT OF SOLID PAPILLARY-CYSTIC TUMOR OF THE PANCREAS - CASE REPORT AND LITERATURE REVIEW
}

\author{
Pancreatectomia distal com preservação esplênica no tratamento de tumores sólido cístico- \\ papilares de pâncreas - relato de caso e revisão da literatura \\ Cleber SOARES-JUNIOR, Carlos Augusto GOMES, Rodrigo de Oliveira PEIXOTO, \\ Camila Couto GOMES, Luciano Augusto JUSTE
}

From the Department of Surgery, Hospital Universitário, Universidade Federal de Juiz de Fora, Juiz de Fora, MG, Brazil.

HEADINGS - Pancreas. Neoplasm. Cystic tumor.

\section{Correspondence:}

Cleber Soares Junior,

e-mail: cleberdoc@ig.com.br

Fonte de financiamento: não há

Conflito de interesses: não há

Recebido para publicação: 09/12/2010

Aceito para publicação: 14/06/2010

DESCRTORES - Pâncreas. Neoplasia. Cisto.
ABSTRACT - Background - Solid papillary-cystic pancreatic tumors have been recognized as a distinct neoplastic disease, whose incidence has increased in recent years with advancements in imaging technology. Case report - Woman 17-year-old consulted with a symptomatic giant homogeneous solid-cystic mass in the pancreatic tail, undergone a spleen preserving distal pancreatectomy, with excision of the splenic vessels. Histopathology revealed epithelium-lined pseudopapillary protrusions, without malignant change. The patient's postoperative course was uneventful. Conclusion Solid papillary-cystic pancreatic tumor has uncommon incidence and silent presentation, a high degree of suspicion on the part of the surgeon is warranted. In early diagnosis, complete resection is curative. The spleen should be preserved, if feasible.

RESUMO - Introdução - Tumores sólido-cístico papilares têm sido reconhecidos como uma doença neoplásica distinta, cuja incidência tem aumentado atualmente em decorrências dos avanços em imaginologia. Relato do caso - Mulher de 17 anos, procurou atendimento médico em virtude de uma massa homogênea sólido-cística em cauda pancreática, e foi submetida a pancreatectomia distal com preservação do baço, apesar da excisão dos vasos esplênicos. Avaliação histológica revelou protrusões pseudopapilares revestidas de epitélio, sem degeneração maligna. A evolução clínica pós-operatória ocorreu sem complicações. Conclusão - Estes tumores têm que ser reconhecidos pelos clínicos, patologistas e radiologistas, e cirurgicamente ressecados com preservação do baço, conquanto apresentam prognóstico favorável.

\section{INTRODUCTION}

S olid papillary-cystic pancreatic tumors have been recognized as a rarely occurring distinct neoplastic disease, whose incidence has increased in recent years with advancements in imaging technology 5 . The condition accounts for $2 \%$ of all cystic exocrine pancreatic tumors, and typically has been diagnosed in adolescent and young adult females, who present with a large mass in the upper abdomen ${ }^{5,6}$

The management of these patients is complex and available data determining which lesion should be operated on are scarce. The knowledge of pancreatic cyst natural history, predictors of malignant change, histological features and spleen bloody supply should be decisive for the surgical approach, mainly as refers to spleen preservation ${ }^{10}$.

\section{CASE REPORT}

Woman 17-year-old consulted with a 2-month-history of severe intermittent back pain. Prior to admission, she had undergone abdominal ultrasound scanning and chest radiography, with the yield of a giant homogeneous cystic lesion in the upper pole of the left kidney. On admission, repeated abdominal ultrasound showed a solid-cystic mass. Abdominal CT scanning showed a $15 \mathrm{~cm}$ cystic 
mass involving the pancreatic tail without invasion of the adjacent organs (Figure 1), and surgical resection was proposed because its potentially malignant behavior.

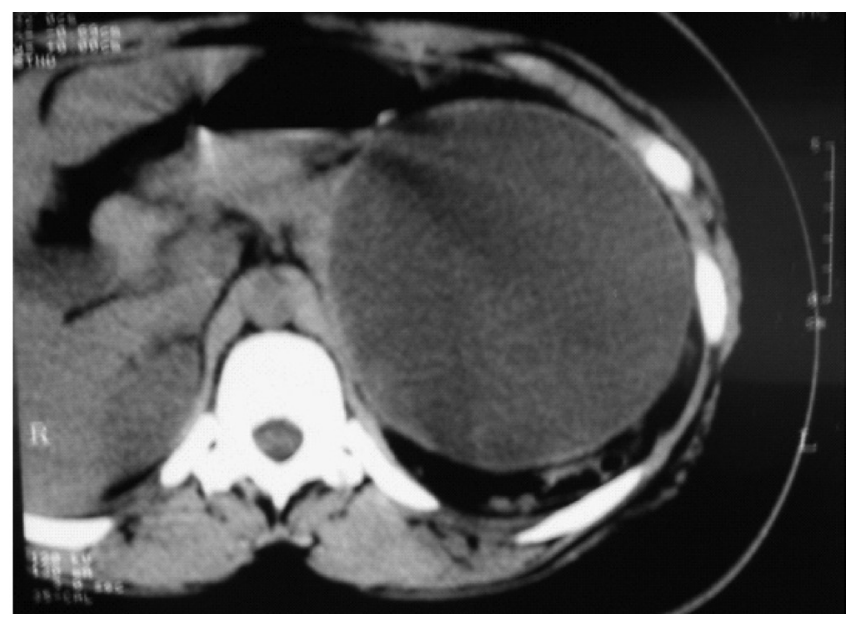

FIGURE 1 - Abdominal CT scan: round homogeneous cystic tumor involving pancreatic tail

Exploration of the abdominal cavity did not show any evidence of adjacent organ infiltration or metastases. A distal pancreatectomy was performed, with complete excision of the cystic tumor. The perioperative frozen section revealed a benign cystic neoplasm. Although the splenic artery and vein had been excised, the spleen was preserved. The procedure involved excision of a knotty tumor mass weighing 550g and measuring 13X09X06 cm.

Macroscopically, the surgical specimen consisted of an encapsulated mass with a fibrous capsule enclosing hemorrhagic and necrotic tissue (Figure 2). On cyst opening, fibrovascular protrusions adherent to the cystic wall were found. Microscopically, the histological features consisted of epithelium-lined pseudopapillary protrusions. No malignant changes were found.

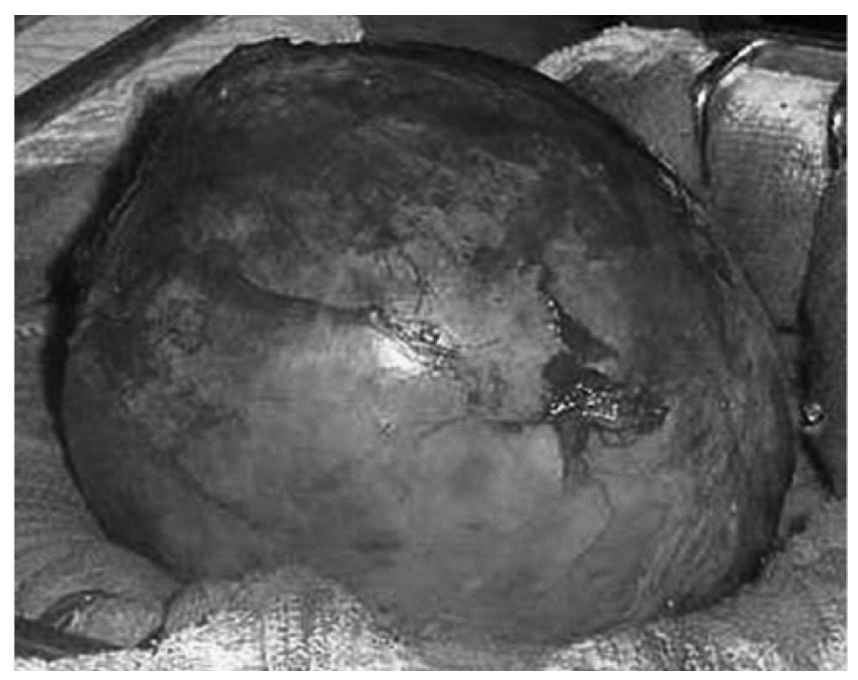

FIGURE 2 - Solid-papillary cystic tumor of the pancreas: operative panoramic view
The patient had an uneventful post-operative course. Oral intake was resumed on the second postoperative day, without vomiting or epigastric fullness. Less than $200 \mathrm{~mL}$ were drained until the 5th day. Hospital discharge happened on the 6th postoperative day, with a Penrose drain set-up. The latter was extracted in the 10th postoperative day when drainage was below $30 \mathrm{~mL} / 24 \mathrm{~h}$. 45 days after surgery the patient was assymptomatic and in very good condition, as she is now, after five years.

\section{DISCUSSION}

Many cystic lesions of pancreas are small and clinically silent, but they may be associated with pancreatitis or have malignant potential. Like this case, most patients are assymptomatic young women. Painlike abdominal discomfort is the main symptom and also the most common one. A palpable mass in the upper abdomen is an important sign. Jaundice and weight loss are rarely seen 7,11 .

Ultrasound and CT scanning, and to a lesser degree angiography, can all suggest the presence of the tumor. CT scanning is the most useful method for characterization of size, shape, and composition of the mass, as well as for definition of organ invasion ${ }^{3}$.

The presence of symptoms, cyst size and solid component has been considered selection criteria to identify patients who are eligible to initial operative management. On the other hand, patients with cystic lesions $<3 \mathrm{~cm}$ in diameter without a solid component may be followed radiographically with a malignancy risk of $3 \%$, that approximates the risk of mortality from resection ${ }^{1}$. Others refer that those preoperative characteristics are not sufficiently reliable in determining malignant potential and thus management approach toward pancreatic cysts lesions ${ }^{4}$.

Macroscopic features in this case are in accordance with literature data: a round homogeneous solid-cystic mass in the upper abdomen. Neither ultrasound nor CT scan showed invasion of the surrounding abdominal organs.

Incidental splenectomy in nonmalignant diseases has been shown to be associated with an increase in infectious complications and higher risk of developing malignancy later in life. Changes in patient's immune system, such as decrease in circulating antibody concentrations, and reduced ability to Kupffer cells to opsonize particulate matter and respond to a antigenic challenge are particularly noteworthy.

Spleen preservation during distal pancreatectomy has been proposed as a means to reduce the risk of postsplenectomy infectious complications, hematologic and immunologic disorders. A possibility is supported with three mainly works cited in the literature ${ }^{2,9,12}$. Spleen preserving distal pancreatectomy with excision of the splenic artery and vein has been indicated to treat enormous benign and low-grade malignant 
disease of distal pancreas. Adequate blood supply and venous drainage via gastroepiploic and gastricsplenic vessels must be guarantied.

Nevertheless Shoup and Brennan emphasize the importance of sparing the splenic vessels when the spleen is to be preserved. The authors call attention to their technique needed less perioperative blood and had significantly fewer postoperative infections ${ }^{9}$. Carrere et al. ${ }^{2}$, underwent 38 consecutive patients to spleen preserving distal pancreatectomy, with excision of the splenic artery and vein. The operation was possible in $95 \%$ of cases and significantly has reduced intra-abdominal infectious complications. It was fast, safe, effective and should be considered in patients with benign or low-grade malignant disease of the pancreas, in despite of two splenectomies performed due to poor splenic perfusion².

In fact there is no evidence in the literature that the immunological competence of the spleen is as good after the resection of the main vessels as it is when those vessels have been retained ${ }^{9}$. Unfortunately in this case it was not performed a study about splenic and pancreas perfusional status, because the patient was asymptomatic with good health in the last followup. With regard to relapse of the pancreatic disease, the abdominal ultrasound scanning didn't show any new cystic lesions.

Despite the typical macroscopic features, peroperative histological examination must be done for diagnostic confirmation. The utmost importance is to exclude ductal adenocarcinoma, when splenectomy in conjunction with distal pancreatectomy is clearly indicated in most patients, as splenic preservation may compromise the oncologic resection.

For distal tumors of pancreas other than adenocarcinoma (endocrine tumors, cystoadenomas, intraductal papillary neoplasia and pancreatic pseudocyst), some authors have advocated spleen preserving distal pancreatectomy as the procedure of choice ${ }^{2,9}$.

The histological findings of a solid papillary-cystic tumor of the pancreas may be unrecognized due to difficult differentiation between exocrine and endocrine pancreatic neoplasms, such as acinar cell carcinoma. The cell origin and the etiology of this tumor are not clear. Microscopic features include endocrine-like solid sheets and branching capillary ribbons surrounding the cystic spaces. The diversity of immunostaining emphasizes the tumor cell phenotype expressing epithelial, mesenchymal, and endocrine lines. Tumor has benign biologic behavior and excellent prognosis, with $90 \%$ survival in the long term after resection ${ }^{3,8}$.

\section{CONCLUSION}

Solid papillary-cystic pancreatic tumor has uncommon incidence and silent presentation, a high degree of suspicion on the part of the surgeon is warranted. In early diagnosis, complete resection is curative. The spleen should be preserved, if feasible.

\section{REFERENCES}

1. Allen PJ, D'Angelica $M$, Gonen $M$, Jaques DP, Coit DG, Jarnagin WR, DeMatteo R, Fong Y, Blumgart LH, Brennan MF. A selective approach to the resection of cystic lesions of the pancreas: results from 539 consecutive patients. Ann Surg. 2006; 244(4): 572-82

2. Carrere $\mathrm{N}$, Abid $\mathrm{S}$, Julio $\mathrm{CH}$, Bloom $\mathrm{E}$, Pradere B. Spleenpreserving Distal Pancreatectomy with Excision of Splenic Artery and Vein: A Case-matched Comparison with Conventional Distal Pancreatectomy with Splenectomy. World J Surg 2006; Dec4; [Published online]

3. Ferlan-Marolt V, Pleskovic L, Pegan V. Solid Papillary-Cystic Tumor of the Pancreas. Hepatogastroenterolog 199; 46: 2978-82

4. Goh BK, Tan YM, Cheow PC, Chung YF, Chow PK, Wong WK, Ooi LL. Cystic lesions of the pancreas: an appraisal of an aggressive resectional policy adopted at a single institution during 15 years. Am J Surg 2006 192(2): 148-54

5. Grouls V, Rakow L. Papillary and cystic neoplasm of the pancreas: Exclusively a tumor of young women? Histopathology 1985; 9: 1245-9

6. Nishihara K, Nagoshi M, Tsuneyoshi M, Yamaguchi K, Hayashi I. Papillary cystic tumor of the pancreas. Assessment of their malignant potential. Cancer 1993; 71: 82-92

7. Rustin RB, Broughan TA, Hermann RE, Grundfest-Broniatowski SF, Petras RE, Hart WH. Papillary cystic epithelial neoplasm of pancreas; a clinical study of four cases. Arch Surg 1986; 121: 1073-6

8. Sanchez JA, Newman KD, Eichelberger MR, Nauta RJ. The papillary cystic neoplasm of the pancreas. Arch Surg 1990; 125: 1502-5

9. Shoup M, Brennan MF, McWhite K, Leung DH, Klimstra D, Conlon KC. The value of splenic preservation with distal pancreatectomy. Arch Surg 2002; 137(2): 164-8

10.Spinelli KS, Fromwiller TE, Daniel RA, Kiely JM, Nakeeb A, Komorowski RA, Wilson SD, Pitt HA. Cystic pancreatic neoplasms: observe or operate. Ann Surg 2004; 239(5): 651-7

11. Warren RB. Papillary cystic tumor of the pancreas. Arch Pathol Lab Med 1985; 109: 706-7

12. Warshaw AL. Conservation of the spleen with distal pancreatectomy. Arch Surg 1988; 123: 550-3 